


\section{Advance Praise for Satellites in the High Country}

"Jason Mark revisits 'the wild' in our landscapes and in our minds. At a time when the wild — as a place and an idea—is being increasingly hemmed in, he offers fresh insights, unsettled questions, and renewed appreciation."

- Curt Meine, Aldo Leopold Foundation and Center for Humans and Nature

"In Satellites in the High Country, gripping accounts of outdoor journeys are linked with provocative thinking about the meaning of wildness in an increasingly human-controlled world. Jason Mark ably continues the writing style and themes of legends such as John Muir and Edward Abbey."

-Roderick Frazier Nash, Professor Emeritus of History and Environmental Studies, University of California Santa Barbara and author of Wilderness and the American Mind

"Satellites in the High Country is an act of ground truthing on the nature of wildness at this moment in time. Author Jason Mark circumnavigates the American West with the eyes of an open-hearted sleuth, looking for what wild remains. Wildness, he discovers, is not only all around us, but inside us as well, having little to do with what is pristine or untouched and everything to do with nature's intricate system of adaptation and response, function and beauty, and our innate capacity for awe. This book is a conversation with sanity."

—Terry Tempest Williams, author of When Women Were Birds

"Jason Mark is a great person to share an adventure with, whether out on the Arctic tundra or on the page. Satellites in the High Country is an engrossing exploration of the ever-evolving definition of what is 'wild' in America-which often reveals as much about us as it does about wilderness in the twenty-first century."

- Michael Brune, Executive Director, Sierra Club

"Satellites in the High Country is a brave and vigorous exploration of wilderness-its meaning, its necessity, its thunderous, rock-strewn reality. Jason Mark guides the reader across mountain passes and Arctic tussocks on a journey that is at once physical, philosophical, and political. His feet may be bruised, but his voice is strong, honest, and compelling. Read this book for an insightful and much-needed update on the centrality of wilderness in the contemporary American mind."

—Kathleen Dean Moore, author of Great Tide Rising 
Satellites in the High Country 



\title{
Satellites in the High Country Searching for the Wild in the Age of Man
}

\author{
Jason Mark
}

OisLandPress Washington | Covelo | London 
Copyright (C) 20I5 Jason Mark

All rights reserved under International and Pan-American Copyright Conventions. No part of this book may be reproduced in any form or by any means without permission in writing from the publisher: Island Press, 2000 M St., NW, Suite 650, Washington, DC 20036

Island Press is a trademark of The Center for Resource Economics.

Library of Congress Control Number: 201594II 86

Printed on recycled, acid-free paper

Manufactured in the United States of America

IO $\quad 9 \begin{array}{lllllllll}8 & 7 & 6 & 5 & 4 & 3 & 2 & \text { I }\end{array}$

All map illustrations by Kristin Link (www.kristinillustration.com).

Lyrics from “THE GLOAMING” by THOMAS EDWARD YORKE, PHILIP JAMES SELWAY, EDWARD JOHN O'BRIEN, JONATHAN RICHARD, GUY GREENWOOD and COLIN CHARLES GREENWOOD appear with permission from Alfred Music Publishing. (C) 2002 WARNER/CHAPPELL MUSIC LTD (PRS). All Rights Reserved.

Keywords: Island Press, Anthropocene, The Human Age, The Age of Man, wilderness, wild, wildness, Aravaipa Canyon, Yosemite, Olympic Mountains, Hoh Rainforest, Olympic National Park, Aichilik River, Arctic National Wildlife Refuge, Gwich'in, Badlands, Black Hills, Lakota, Gila Wilderness, pristine, Mexican Gray Wolf, rewilding, Lynx Vilden, Stone Age Living Project, Google Treks, Columbian Exchange, wildling, naturalness, geoengineering, climate change, untrammeled, Outward Bound, Pine Ridge Reservation, powwow, Aldo Leopold, John Muir, the land ethic, The Wilderness Act, William O. Douglas, Henry David Thoreau, Charles Darwin, evolution, conservation, conservationists, environmentalists, ecology of fear, Yosemite National Park, Shelton Johnson, frontier, Theodore Roosevelt, America's Best Idea, Drakes Bay Oyster Farm, Point Reyes National Seashore, William Cronon. 
For those who cannot live without wild things 

What would the world be, once bereft Of wet and wildness? Let them be left, $\mathrm{O}$ let them be left, wildness and wet;

Long live the weeds and the wilderness yet.

— Gerald Manley Hopkins, "Inversnaid” 



\section{Contents}

Prologue: Into the Wild I

Chapter I. Bewildered II

Chapter 2. The Mountains of California 39

Chapter 3.The Forest Primeval 7I

Chapter 4. Fall of the Wild? 93

Chapter 5. The Heart of Everything That Is I3I

Chapter 6.The Ecology of Fear I69

Chapter 7. Back to the Stone Age $\quad$ I99

Epilogue:Wild at Heart 233

Acknowledgments 25I

Sources \& Inspiration 255

Interviews $\quad 257$

Notes 26I

Bibliography 289

Index 299 